УДК 821.163.41.09 Држић, М. https://doi.org/10.18485/msc50.2019.1.ch43

\author{
Злата Бојовић
}

\title{
ДУБРОВАЧКЕ РЕНЕСАНСНЕ ТРАГЕДИЈЕ И СТВАРНОСТ
}

\begin{abstract}
У другој половини XVI века настало је у Дубровнику пет трагедија. Све су биле препеви и прераде античких и ренесансних трагедија. Прва је била Хекуба Марина Држића (1558), то јест препев-прерада италијанског препева Еврипидове трагедије коју је сачинио италијански ренесансни писац Лодовико Долчи. Преводећи је, Држић је на разне начине садржај актуализовао (илузије на савремени морал, на власт, христијанизација и др.) и тако створио модел који ће следити остали аутори (Михо Бунић Бабулиновић, Франо Лукаревић, Доминко Златарић, Савко Гучетић Бендевишевић).
\end{abstract}

Кључне речи: ренесанса, трагедија, препев-прерада, Марин Држић, Хекуба.

Године 1558. сасвим изненађујуће за све који су Марина Држића знали, а за његове суграђане највише, који су једну деценију пратили како их из године у годину увесељава о покладама, често на свадбеним свечаностима, комедијама, еклогама и досеткама, овај велики забављач је доживео да његово последње дело буде два пута забрањено за извођење. То је била драма какву до тада Дубровчани још нису писали, Држићев препев, односно прерада Еврипидове трагедије Хекуба, и то према посредној парафрази италијанског ренесансног писца Лодовика Долчеа, који је превео на италијански језик готово све велике античке трагедије. Нема сумње да је Држићев рукопис трагедије, коју је за извођење припремала аматерска дружина, доспео у руке неком од чланова дубровачке владе, те је она, то јест њено важно тело, Мало веће, забранило представљање предвиђено за 9. март 1558, као и друго, будући да аутор и његова дружина, по свему, нису одустајали од намере да Хекубу играју, које је имало да буде 21. маја исте године. ${ }^{1}$ Не зна се шта је замерено у првом одбијању да се изда дозвола за представу, нити да ли је аутор нешто изменио и поново поднео трагедију на увид, што би било логично, али је друга одлука цензуре била јасно образложена: „Не допушта се да се трагедија прикаже

${ }^{1}$ М. Пантић, Прилози за историју ренесансног позоришта у Дубровнику, 4. Држићева „Хекуба” и дубровачки платоничари, Зборник историје књижевности Одељења литературе и језика САНУ, 1962, 3, 208-209. 
у Граду због тога што је време такво да није потребно оно што смућује”. И поред два неуспела покушаја, Држић и даље није одустајао од своје намере. Остало је непознато да ли је нешто изменио, можда и према усменим сугестијама, али следеће, 1559 . године ${ }^{2}$, у дане поклада, то значи из трећег покушаја, Хекуба је добила дозволу да буде изведена у Дубровнику.

У тражењу одговора којим се мотивом руководило Мало веће када је најпре два пута забранило, па потом дозволило представљање Хекубе, налазило се, као логично, тумачење да је у првом случају то била воља следбеника платонистичке поетике и филозофије, а њих је у овој ренесансној књижевној средини била већина, по којој је, као што је познато, трагедија била неподобна будући да делује јаким емоцијама и страстима. Следеће године, према тој претпоставци ${ }^{3}$ могли су међу онима који одлучују бити бројнији аристотеловци, па је одобрење дато. Ове претпоставке ипак не дају одговор на основно питање: зашто је Марин Држић одлучио да преради трагедију, како је уобичајено, и зашто је одабрао Хекубу, која се сматрала једном од „најкрвавијих” античких трагедија и зашто је био толико упоран да је његови суграђани виде. И даље, шта би у тој трагедији било у то време опасно по гледаоце у Граду, то јест у Дубровнику, и изазвало „оно што смућује”.

Сама по себи, античка Хекуба, уз сву драматичну трагику, убиства и сурове призоре, не би представљала тако велику претњу за гледаоце јер је њен садржај ондашњим грађанима био познат, будући да је ова врста античке књижевности била устаљена лектира хуманистичке школе. Држићев препев - а у то време препев је схватан знатно шире јер се поетика превода разликовала, то је претежно била прерада, која је допуштала проширења и значајне слободе и прихватан је као оригинално дело - морао је да садржи нешто чега није било у Еврипидовој Хекуби, нешто што је погађало његове савременике непосредно, нешто што је била претња друштвеном миру у том, по нечему осетљивом тренутку и што је цензура Малог већа проценила као опасност.

Хекуба, најпре Еврипидова, потом италијанског преводиоца Лодовика Долчеа и посредника између најстарије, грчке и Држићеве верзије, сведена је на један од најтрагичнијих догађаја у Тројанском рату: представљала је краљицу Хекубу, жену тројанског краља Пријама, мајку седамнаесторо деце (Хектора, Париса, Полидора, Поликсене и других), од којих су скоро сва страдала у рату, она била заробљена, потом погођена

${ }^{2}$ F. Fancev, Naučna istraživanja starije hrvatske književnosti godine 1933. i 1934, Ljetopis JAZU, 1935,47, 121.

${ }^{3}$ М. Пантић, Исто. 
највећим болом и увредом јер је доживела да Ахил оскрнави леш њеног најмилијег сина Хектора; доживела је затим још дубљу трагедију када се, пошто је видела смрт жртвоване кћери Поликсене и сина Полидора, осветила њиховом убици, похлепном Полиместру убиством његове деце. Подстакла је, додуше, пошто је трагедија измакла свим разлозима, овим чином Агамемнона на разумно просуђивање: ослепелог убицу (Полинестра) је прогнао на пусто острво, њој дозволио да сахрани сина, а остале робиње ослободио.

Шта је у овом догађају, који је припадао давном митолошком свету, препознао Држић као рефлекс у свом времену и определило га за Еврипидову тргедију, тачније за Хекубину судбину за предмет новог дела? Како је у досадашњем компаративистичком истраживању, додуше још увек не у потпуности детаљном, показано, италијански превод, којим се служио Држић, није примио већи нанос времена у коме се поново Хеку$б a$ актуализовала, али је чињеница да је баш ова грчка трагедија више пута прерађивана у доба ренесансе и у другим књижевностима.

Држићева трагедија више од свих других маркирана је стварношћу, и то не реалијама којима су преводиоци често прибегавали како би прилагодили старо дело новом времену (то је и сам Држић радио прерађујући Плаутове комедије), већ наглашавањем, чак и проширивањем свих оних места која су се поклапала са стварношћу са којом је живео. У садржинском слоју, то је била стварност аристократског Дубровника XVI века; у преиспитивању зла, које је било судбинска суштина главног јунака, то је била христијанизација свега што је алудирало на пролазну моћ земаљске силе; у мисаоном слоју то је била филозофија времена; у књижевном слоју то су били интермедијски додаци и пасторални елементи.

Где се то могла у ткиву Хекубе, то јест у предалекој причи о трагичној судбини тројанске јунакиње, препознати стварност аристократског Дубровника?

Посматрајући Држићево стварање у целини, Хекуба је настала у годинама када су се у њему већ нагомилала разочарења и неправде и многа незадовољства.

Искусио је до тада више пута моћ закона над слабима, суревњивост савременика - познато је место из Дунда Мароја на коме фином иронијом описује сопствено осећање:

„није га бит поета ни комедије умјет чинит, ер тизијем свак оре и на сваки га пијер хоће операт, као бастаха, а умјесто захваљења да му реку: „Не ваља ништа, иждени!” и да му непријатељи остану; није га бит мужик ер тизијех друзи чине пјет кад већу вољу плакат имају". 
Из каснијих пишчевих подухвата (којих је могло бити и више, а само о једном се сазнаје из сачуваних завереничких писама), који припадају времену од неколико година после настанка Хекубе, види се да је имао многе замерке дубровачкој власти, толике да се заносио организовањем побуне и променом устројства државе, у којој би власт у будућности делили патриције и грађани. Није битно да ли је та његова побуна била реална, али је јасно да је била искрена, додуше смела и тада неразумна реакција на неправду и моћ оних који владају.

Стихови Хекубе, којима се прати њена судбина, највећим делом баве се питањем правде и праведног суђења и чињеницом да онај ко влада и има моћ може све, да се његова реч слуша, ма и непаметна, а човек без права, роб (у античкој причи), односно грађанин, не може да се носи са силом власти („добро т' не стоји с јачим се рвати”). Та је моћ велика јер државни разлози - виши од сваког појединачног - оправдавају све. Све Хекубине молбе да спаси живот својој преосталој деци, наилазе на разумевања њеног непријатеља док је слуша као несрећну мајку, али и на потпуно одбијање и немилост када све посматра у име неприкосновености државног разлога. У тим тачкама Држић је, читајући Хекубу, нашао своје време, његове накарадне законе, његове неправде, ароганцију властеле и определио се да својим савременицима представи Хекубу као прекор, као опомену, као глас стварности коју власт не жели да чује. На таквим местима у препеву, на којима је осетио своје време, Држић га је шире, директније и наглашеније коментарисао:

Човјека од власти сваки свјет има влас,

а ки је без части, није чувен мудар глас. (875-876)

У овим стиховима одзвањају мисли и других дубровачких ренесансних песника о томе да у тадашњем друштву „мудар глас” нема никакву снагу јер се поштују само моћни (Ветрановић) - дакле о стварности. На ту се стварност у највећој мери непосредно односи, иначе у размишљањима о владару познато резоновање о потреби да онај коме је у руке дат закон мора да буде праведан:

У руке вам на свит правда је, закон дан, без вас се сахранит не море праведан чините, ком доли /односи се на реалну власт/ дано је владати да се прав не боли и да прав не пати.

Ер ако злоба уз вас владаоце моћ стече, слатки мир, покој вас од људи утече... (1956-1961) 
Има мишљења да је управо ово опомињање власти која се заборавила у сили, која не мисли на правду, која двоструким моралом штити државни разлог, био прави узрок забране извођења Хекубе која је могла да унесе немир у живот града и државе и да „смућује”:

Има се мислити ер свака слава и моћ под сунцем на свити на мање има доћ... (585-586)

Уколико није било још нечег у тексту трагедије који је првобитно забрањен, а Држић га је могао потом преиначити да би био одобрен, сасвим је могуће да је овако директно певање против власти, против неправедног суда, против надмоћи, против непоштовања сваког гласа онога ко је испод ње, уз опомену да је пролазна, било непосредно уперено против тадашњег аристократског начела. То је још и појачано супротношћу: paзумним, уравнотеженим Агамемноновим поступцима, спремношћу да у сваком сукобу саслуша обе стране, не стајући одмах на страну повлашћене - „правда овди јес ; / свак реци разлог свој, а ја ћу судити”.

Опште је познато да је дубровачка стварност вековима била обележена непрестаном борбом за стицањем, што је било оличено у трговцима и трговини као највиталнијем корену њеног материјалног успона, али и у својеврсној деструкцији морала и спокојног живота. Држић је на више места и на разне начине, и у другим делима, попут других савременика, опомињао на порок похлепе којој се тешко ко у том свету, који су устројавали други морални закони, могао отети. У Хекуби је нашао погодну основу у лику лакомог Полиместра, који је због злата убио Хекубиног сина Полидора, за оштре речи о грамзивости у чијој власти људи - слободно се може рећи у алузији Дубровчани - заборављају на највеће вредности („при злату велику вјеру и час... заби”; „цјећ злата оцкврнит ктје... виру и стан").

Држићевом времену би у свему припадале и све оне рефлексије о пролазности моћи и власти, о временитости свега на свету, јер је и то била једна од опомена, потпуно у духу размишљања о пролазности свих моћи овога света. Таквим рефлексијама Држић је христијанизовао античку основну причу и у потпуности је подвео под хришћанско виђење свога времена (непрестана су обраћања „вишњему” да помогне у невољи и у неправди; једино небеска правда „зличинце свуд дохита”; у последњем стиху хор пева да суду „згар”, са неба, „није моћ утећи никадар” и сл.).

Занимљиво је да је и књижевна стварност утицала на ово дело. Осим тога што је Држић унео између чинова оригиналне интермедије, они су припадали ренесансном пасторалном свету вила и сатира, што је у потпуности изван изворне трагедије. Њима је дато да, уместо хорова, 
сентенциозно коментаришу збивања. То је био дуг стварности јер су у то време на највишој цени биле пасторале, а на то је изричито упућивао пролог у његовој комедији Скуn. Било је у потпуном складу са савременим књижевним тренутком што је Држић у препев једне античке трагедије уводио пастирски свет, који у мизансцену уз звуке инструмената игра и збори.

Са Хекубом је тек почетком друге половине XVI века у дубровачку књижевност и у театар ушла трагедија. По свему, Држић је својим начином препева и парафразе Еврипидове трагедије, то јест њеног посредног италијанског препева, створио модел за овај књижевни поступак, па су све трагедије које су настале до краја XVI века, следећи га, постепено обликовале поетику трагичког. Био је то невелики број од пет трагедија - овај жанр, по природи времена које би требало да прими у своје садржаје, у веку епикурејских начела није могао да заузме битније место - а чиниле су га: Јокаста Миха Маровог Бунића, која је била превод - „у словински” језик „истомачена” - Еврипидове трагедије Феничанке, и то преко италијанског препева Лодовика Долчеа, Атаманте Франа Лукаревића, а била је препев италијанске трагедије Џиролама Зопија, Елекmра коју је Доминко Златарић препевао са грчког, Софокловог оригинала и Далида Савка Гучетића Бендевишевића, која је такође препев, у коме су спојене две италијанске трагедије, Адријана Луиђија Грота и Орбека Џамбатисте Џиралдија Чинтија.

Пред сваку од ових драма може да се постави исто питање као и пред Држићеву Хекубу - зашто је писац баш њу одабрао за дубровачке гледаоце и читаоце (верујемо да су неке од њих биле првенствено намењене читању), шта је свака од њих појединачно имала да пружи новом времену и да се оно у њој препозна. Јер без те релације са стварношћу ниједно од ових дела у дубровачком препеву не би имало смисла. Свака од њих, баш како је то било код Држића, морала је да споји у себи са познатом садржином и савремени тернутак и тиме сама себе актуализује. По општем суду најбољи преводилац, Златарић, пред Електром је објаснио да он намерава да представи „штогоди давње”, што је у себи садржало нешто „од висока и од племенита”, а то би значило нешто што погодује његовом времену, што се подудара са узвишеним и племенитим. Од свих преводилаца Златарић се најмање удаљио од античког оригинала, али и код њега је све имало да се подразумева у савремености, од посвете савременику, преко потпуне христијанизације, преко низа подударних рефлексија са Држићем, управо оних које су одговарале једној духовној страни епохе, о пролазности, о власти времена над „стварми људскиме”, о распусности, о аристократској етици, која је у XVI веку била изразита 
особеност - „зач племенит ниткор неће / оцкврнити свитло име” - а истовремено и критика морала осталих друштвених слојева итд.

Питање зашто је трећа трагедија, Јокаста, заснована на миту о Едиповој мајци и супрузи, препевана, можда у највишој мери добија одговор у изразито наглашеној и развијеној теми култне љубави према родном месту у доба хуманизма и ренесансе. У њој су се нашле стотине стихова о величини љубави према родном граду, у коме се препознаје Дубровник, као најважнијег осећања које један поданик Републике у XVI веку носи:

„крозтој има бит над ино све благо

умрлим на сај свит мјесто родно драго;

над ствари ине, има се град љубит”. (697-698; 1411)

На њих се надовезују и низови стихова који носе дух времена које је пред појавом барока започињало своја велика размишљања о пролазности и о променљивости и несталности света.

И за Атаманту Франа Лукаревића, која је оцењивана као невешти препев, може се подржати мишљење које је још Армин Павић изнео да је садржала низ одступања у односу на изворно дело „преиначујући оно што је вријеђало његове вјерске осјећаје или његова политичка увјерења". У том преиначењу садржани су и други, много непосреднији одјеци времена, опаске ауторове о подређеном положају жене у Дубровнику у његово доба („жене су нејаке, мноштва их не сцине”, „ни им се пристоји по туђих странах ит"), о често понижавајућем њиховом социјалном положају:

„да се чим имају дјевице прихранит

најлјепши продају чистоће своје цвит",

о односу у породици и слободном понашању мужева, што је већ више пута књижевност забележила („ки жене пуштају, с ким их Бог садвоји / а с других дни трају, што веома зло стоји”). На своје време је мислио Лукаревић и када је низао изјаве о дубровачкој власти и владању, подржавајући политику своје државе.

У односу који постоји између Атаманте и дубровачке средине и времена садржан је одговор зашто се ово дело нашло на репертоару дубровачких трагедија друге половине XVI века.

Можда је најдраматичнија од свих крвавих дубровачких трагедија била Далида Савка Гучетића Бендевишевића. Овај писац мало познате биографије једва што се зна да је рођен 1531. и умро 1603 - у својој трагедији спојио је две његовом времену блиске драме. Комбинујући два извора, Бендевишевић је имао више слободе и отуда је његова трагедија препуна 
живота и смислова његове стварности. Највише се то односи на нови лик на дубровачкој позорници, који се до тада није сусретао, а који је одражавао време - нови лик жене побуњене против ропског положаја у породици, против родитељског господарења судбином кћери, против срачунатог брака. Да је изведена пред дубровачком господом, Далида би била неразумно слободна. Њен лични бунт и одлучност били су израз непокорности пред до суровости строгим породичним законима који су одражавала животну стварност и само привидно слободног човека. Трагична судбина Далиде која је, без кривице, вођена само осећањем искрене љубави, зато што се огрешила о патријархална правила, кажњена убиством мужа и деце, кажњена и сопственом мржњом поставши очев убица, није била само нека далека заплетена крвава прича. Све што се у њој збивало припадало је не античком већ пишчевом времену. Позивање на древни породични ред ствари:

„није ли божји суд и закон од свита послухом да се свуд родитељ почита",

Далида одважно оповргава, не из непоштовања већ у име грубе стварности која у потпуности поништава сваку слободу у човеку:

„ласно ниј узети за мужа, вај мени, с ким имам на свијети прибиват све ме дни прије нег сам познала тко је он и какав...”

Оваква одрешитост морала је онеспокојавати Гучетићеве саврменике јер је подривала ионако пољуљану тврђаву све рањивијег властеоског сталежа. Толико су директно и оштро говорили о времену, о моралу, о моћном закону новца да је тешко поверовати да би се дозволило да јавно на позорници све то буде изречено јер Далидина трагична судбина ту стварност није скривала својом причом већ је још и појачавала.

Свака од пет дубровачких трагедија појединачно, али и све заједно будући да се у њима васпоставила сасвим специфична, затворена поетика, представљајући фабулом далеке светове, најкрвавије митолошке приче, које су опонашале највеће људске драме, оствариле су преносне мостове са новим временом. Ни у једном тренутку нису њихови нови смислови прелазили у баналну алегорију. На најфинији, али и на најприроднији начин, њихови аутори-преводиоци следили су само једно правило: препевавајући, они би рекли „тумачећи” познате трагедије нису мислили на јунаке старих драма, чије су судбине пратили, већ на своје савременике. Као у огледалу, стара фабула је тако постајала одраз стварности. 
Злата Бойович

ДУБРОВНИЦКИЕ РЕНЕССАНСНЫЕ ТРАГЕДИИ И ДЕЙСТВИТЕЛЬНОСТЬ

Резюме

В эпоху ренессанса во второй половине XVI века появилось всего пять трагедий. Все они представляли свободный перевод-переделку античных греческих или итальянских ренессансных трагедий. Трагедии не переводились прямо с греческого (за исключением Электры Софокла, которую свободно переделал Д. Златарич), а через посреднический итальянский перевод. Общей характеристикой всех поэтических переработок является приспособление древних текстов современной жизни (христианизация; аллюзии на современную жизнь, на мораль, на власть, на патриархальные законы и т. п.). Автором первой поэтической переделки был Марин Држич (он осуществил свободный перевод Гекубы Еврипида, пользуясь итальянской переделкой Л. Долче); за манерой Држича следовали все остальные переводчики. 